\title{
Relationship between primary aldosteronism and obstructive sleep apnoea, metabolic abnormalities and cardiac structure in patients with resistant hypertension
}

\author{
Związek pomiędzy pierwotnym hiperaldosteronizmem a obturacyjnym \\ bezdechem sennym, zaburzeniami metabolicznymi oraz strukturą serca \\ u chorych na oporne nadciśnienie tętnicze
}

\begin{abstract}
Aleksander Prejbisz', Elżbieta Florczak', Anna Klisiewicz' ${ }^{2}$, Piotr Dobrowolski ${ }^{2}$, Hanna Janaszek-Sitkowska', Przemysław Bieleñ ${ }^{3}$, Elżbieta Szwench-Pietrasz', Ewa Warchoł-Celińska', Sylwia Kołodziejczyk-Kruk', Jadwiga Janas ${ }^{4}$, Marek Kabat ${ }^{1}$, Jacek Imiela ${ }^{5}$, Paweł Śliwiński ${ }^{3}$, Andrzej Januszewicz ${ }^{1}$
\end{abstract}

${ }^{1}$ Department of Hypertension, Institute of Cardiology, Warsaw, Poland

${ }^{2}$ Department of Congenital Heart Diseases, Institute of Cardiology, Warsaw, Poland

${ }^{3} I V$ Department of Respiratory Medicine, Institute of Tuberculosis and Lung Diseases, Warsaw, Poland

${ }^{4}$ Department of Clinical Biochemistry, Institute of Cardiology, Warsaw, Poland

${ }^{5}$ Department of Internal Medicine and Nephrology, Międzyleski Hospital, Warsaw, Poland

\begin{abstract}
Introduction: The aim of this study was to evaluate in patients with resistant hypertension (RHTN) enrolled in the RESIST-POL study the relationship between primary aldosteronism (PA) and obstructive sleep apnoea (OSA) and their effect on metabolic abnormalities and cardiac structure. Material and methods: We included 204 patients ( $123 \mathrm{M}, 81 \mathrm{~F}$, mean age $48.4 \mathrm{yrs}$ ) with true RHTN, eGFR > $60 \mathrm{~mL} / \mathrm{min} / 1,73 \mathrm{~m}{ }^{2}$ and no known diabetes. OSA was defined as an apnoea/hypopnoea index of $15 / \mathrm{h}$ or more. Metabolic syndrome components were assessed. On echocardiography, left ventricular hypertrophy (LVH), concentric remodelling (RWT > 0.45), E' velocity, E/E' index and global strain (GLS) were evaluated. Results: PA was diagnosed in 32 patients (15.7\%). OSA occurred more frequently in patients with PA (59.4 v. 42.4\%; $\mathrm{p}=0.058)$. Patients were divided into four groups: PA+ OSA+ , PA+ OSA-, PA-OSA+ and PA-OSA-. Newly diagnosed diabetes, impaired glucose tolerance and increased fasting glucose were most frequent in the PA+ OSA + group compared to other groups. The presence of OSA was associated with concentric remodelling, and the presence of PA was associated with higher left ventricular mass and higher frequency of left ventricular hypertrophy. In the PA+ OSA + and PA+ OSA- groups, the most frequent geometry patterns were concentric hypertrophy $(68.4 \%)$ and eccentric hypertrophy $(54.5 \%)$ respectively. $E^{\prime}$ velocity was lowest and E/E' was highest in PA+ OSA+ compared to other groups. GLS was lower in patients with OSA compared to those without OSA.

Conclusions: Both metabolic abnormalities and target organ damage are more pronounced in patients with RHTN, PA and OSA. OSA and PA influence differently left ventricular geometry. (Endokrynol Pol 2013; 64 (5): 363-367)
\end{abstract}

Key words: resistant hypertension, obstructive sleep apnoea, primary aldosteronism, metabolic syndrome, left ventricular hypertrophy

\section{Streszczenie}

Wstęp: Celem analizy była ocena związku pomiędzy pierwotnym hiperaldosteronizmem (PA) i obturacyjnym bezdechem sennym (OBS) $\mathrm{w}$ relacji do nasilenia zaburzeń metabolicznych i zmian struktury i funkcji lewej komory (LV) serca u chorych z prawdziwie opornym nadciśnieniem tętniczym (OPNT) włączonych do badania RESIST-POL.

Material i metody: Badaniem objęto 204 chorych $(123 \mathrm{M}, 81 \mathrm{~K}$, średni wiek 48,4 lat) z OPNT, eGFR > $60 \mathrm{ml} / \mathrm{min} / 1,73$ m² i bez rozpoznanej wcześniej cukrzycy. Istotny klinicznie OBS zdefiniowano, jako wskaźnik bezdechów i oddechów spłyconych (AHI) > 15/h. Oceniono składowe zespołu metabolicznego (MS). W badaniu echokardiograficznym oceniono: przerost LV (LVH), koncetnryczną przebudowę LV (RWT > 0,45), prędkość fali E', wskaźnik E/E' i globalne odkształcenie włókien podłużnych (GLS).

Wyniki: PA rozpoznano u 32 chorych (15,7\%). OBS występował częściej u chorych z PA $(59,4$ v. 42,4\%; p = 0,058). Chorych podzielono na cztery grupy: PA+ OBS+ , PA+ OBS-, PA-OBS+ and PA- OBS-. Świeżo wykryta cukrzyca, podwyższone stężenie glukozy na czczo i podwyższone stężenie glukozy po obciążeniu glukozą występowały najczęściej w grupie PA+ OBS +. OBS związany był z częstszym występowaniem koncentrycznej przebudowy LV, podczas gdy PA związany był z wyższą masą LV i częstszym występowaniem LVH. W grupach PA+ OBS + I PA+ OBS - najczęstszymi typami geometrii LV były odpowiednio: przerost koncentryczny (68,4\%) i przerost ekscentryczny $(54,5 \%)$. Prędkość fali E' była najniższa i wskaźnik E/E' był najwyższy w grupie PA+ OBS + . GLS był niższy u chorych z OBS w porównaniu z chorymi bez OBS.

Wnioski: Zarówno zaburzenia metaboliczne jak i nasilenie zmian narządowych były najbardziej wyrażone u chorych z OPNT, u których współistniały PA i OBS. PA i OBS w różny sposób wpływały na geometrię LV. (Endokrynol Pol 2013; 64 (5): 363-367)

Słowa kluczowe: nadciśnienie tętnicze oporne, pierwotny hiperaldosteronizm, obturacyjny bezdech senny, zespół metaboliczny, przerost lewej komory

This study was supported by the Ministry of Science and Higher Education NN 402190335. 


\section{Introduction}

The prevalence of primary aldosteronism (PA) in the general hypertensive population remains an unresolved issue, but data from clinical practice indicates that resistant hypertension (RHTN) represents the condition with the highest probability of detecting PA [1-4]. Recent studies have indicated that in PA exposure to inappropriately elevated aldosterone might result in substantial cardiovascular and renal damage. One study that has reported prospective data upon treatment of PA found a higher cardiovascular and cerebrovascular risk for patients with PA at baseline [5].

The association of obstructive sleep apnoea (OSA) in hypertension is particularly marked among patients with RHTN, with studies reporting an OSA prevalence of $80 \%$ to $85 \%$ in these patients [6,7]. As in other diseases resulting from hormonal disturbances, the nondipping pattern of blood pressure during the night has been reported as a feature of patients with OSA [8]. Obstructive sleep apnoea is associated with increased cardiovascular morbidity and mortality. Recent data suggests that OSA is independently associated with the cardiovascular risk factors that comprise metabolic syndrome (MS) and its components [9, 10].

In the RESIST-POL study, we have recently shown that in the studied group of 204 patients with true RHTN, the prevalence of PA was 15.6\%. PA also overlapped with MS and OSA [6]. Because the coexistence of PA and OSA in patients with resistant hypertension has been reported only by a few authors, we analysed the relationship between PA and OSA, metabolic abnormalities and cardiac structure in patients with true resistant hypertension enrolled in the RESIST-POL Study $[6,11,12]$.

\section{Material and methods}

Consecutive patients aged 18-65 years with RHTN, confirmed on ambulatory blood pressure monitoring, with preserved renal function (eGFR $>60 \mathrm{~mL}$ / $/ \mathrm{min} / 1.73 \mathrm{~m}^{2}$ ) and with no history of known diabetes, referred to the Department of Hypertension, Institute of Cardiology, Warsaw Poland between 2009 and 2011, were included in the Resist-Pol study. The study was approved by the Ethics Committee of the National Institute of Cardiology, Warsaw and informed written consent was obtained from each patient [6].

The full protocol and main results of the RESISTPOL study have been already published. In brief, patients with true RHTN were screened for coexisting conditions including metabolic abnormalities and OSA, secondary causes of HTN including PA as well as evaluated for target organ damage. As the methodology of the RESIST-POL study has been described extensively previously, we summarise below the definitions used for the purpose of this analysis [6].

Abdominal obesity was defined as waist circumference $>102 \mathrm{~cm}$ and $>88 \mathrm{~cm}$ for women and men respectively [13]. Microalbuminuria was defined as $24 \mathrm{~h}$ albumin excretion $>30 \mathrm{mg} / 24 \mathrm{~h}$. Glucose and lipid metabolism abnormalities were diagnosed on the basis of the 2007 European Society of Hypertension/European Society of Cardiology (ESH/ESC) guidelines - increased fasting plasma glucose FPG: $\geq 5.69 \mathrm{mmol} / \mathrm{L}$; increased $2 \mathrm{~h}$ post glucose $(2 \mathrm{hPG})$ loading glucose concentration: $\geq 7.8 \mathrm{mmol} / \mathrm{L}$; diabetes was diagnosed if two measures of FPG were $\geq 7.0 \mathrm{mmol} / \mathrm{L}$ or $2 \mathrm{hPG}>11.0 \mathrm{mmol} / \mathrm{L}$ [13]. For diagnosis of metabolic syndrome, three out of five criteria had to be met: (1) $\mathrm{BP} \geq 130 / \geq 85 \mathrm{~mm} \mathrm{Hg}$ - this criterion was met for all patients; (2) abdominal obesity - waist circumference $\mathrm{M}>102 \mathrm{~cm}, \mathrm{~F}>88 \mathrm{~cm}$; (3) HDL cholesterol $\mathrm{M}<1.0 \mathrm{mmol} / \mathrm{L}, \mathrm{F}<1.2 \mathrm{mmol} / \mathrm{L}$; (4) triglycerides $>1.7 \mathrm{mmol} / \mathrm{L}$; and (5) FPG $\geq 5.6 \mathrm{mmol} / \mathrm{L}$ [13].

To screen for PA, the plasma aldosterone to renin ratio (ARR) was evaluated in all patients. To confirm the diagnosis of PA, further testing was performed in patients with increased ARR $(>30)$ and serum aldosterone concentration (> $15 \mathrm{ng} / \mathrm{dL}$ ). The captopril challenge test was conducted to confirm the diagnosis of PA, which was made in patients showing failure of aldosterone to suppress more than $30 \%$. Medication treatment was tailored according to current guidelines [3, 14-16]. Contrast enhanced computer tomography was performed in each patient for the purpose of adrenal gland imaging [17].

All patients irrespective of the symptoms of OSA were evaluated by standard attended polysomnography. The apnoea/hypopnoea index (AHI) indicating the number of apnoeic and hypopnoeic episodes per hour of sleep was calculated. For the purpose of this study, we defined OSA as AHI above 15/h indicating clinically significant moderate-to-severe OSA.

The left ventricle mass (LVM) was calculated using the modified American Society of Echocardiography cube formula proposed by Devereux et al. and was indexed to body surface area to obtain the LVM index (LVMI) [18]. Left ventricular hypertrophy was defined as a LVMI $\geq 110 \mathrm{~g} / \mathrm{m}^{2}$ for women and $\geq 125 \mathrm{~g} / \mathrm{m}^{2}$ for men. Concentric geometry was present when relative wall thickness (RWT) $>0.45$ [19]. Left ventricular systolic function was evaluated by left ventricular ejection fraction. Additionally, using speckle tracking echocardiography, global longitudinal strain (GLS) was obtained. Left ventricular diastolic function was evaluated by mitral inflow velocities and TDI values and included: the ratio of the early (E) to late (A) diastolic peak transmitral flow velocity (E/A ratio), myocardial early-diastolic velocity $\left(\mathrm{E}^{\prime}\right)$, and the $\mathrm{E} / \mathrm{E}^{\prime}$ ratio.

Data analysis was carried out using statistical software PASW Statistics 18 (SPSS Inc., Chicago, IL, USA). The re- 
Table I. Clinical characteristics of patients in relation to the presence of obstructive sleep apnoea (OSA) and primary aldosteronism (PA)

Tabela I. Charakterystyka kliniczna chorych w zależności od wspótistnienia obturacyjnego bezdechu sennego (OSA) i pierwotnego hiperaldosteronizmu (PA)

\begin{tabular}{|c|c|c|c|c|c|}
\hline & OSA- PA- & $O S A+P A-$ & OSA-PA+ & $\mathrm{OSA}+\mathrm{PA}+$ & p-value \\
\hline Subjects $n$ & 99 & 73 & 13 & 19 & \\
\hline Men/women & $41 / 58$ & $59 / 14$ & $8 / 5$ & $15 / 4$ & $<0.001$ \\
\hline Age (years) & $45.7 \pm 10.8$ & $50.8 \pm 9.4$ & $49.8 \pm 13.7$ & $52.5 \pm 8.2$ & 0.003 \\
\hline BMI $\left[\mathrm{kg} / \mathrm{m}^{2}\right]$ & $28.7 \pm 4.6$ & $31.7 \pm 4.5$ & $28.3 \pm 3.4$ & $32.6 \pm 3.3^{*}$ & $<0.001$ \\
\hline Number of antihypertensive drugs ( $\mathrm{n}$ ) & $4(3-5)$ & $4(4-5)$ & $5(3-5.5)$ & $5(4-6)$ & 0.082 \\
\hline Abdominal obesity (\%) & 61.6 & 86.3 & 61.5 & 89.5 & 0.001 \\
\hline Increased fasting glucose (\%) & 44.4 & 60.3 & 61.5 & 73.7 & 0.045 \\
\hline Increased 2hPG (\%) & 15.4 & 40.9 & 63.6 & $66.7^{1}$ & $<0.001$ \\
\hline Newly recognised diabetes (\%) & 5.1 & 19.2 & 15.4 & $42.1^{1, *}$ & $<0.001$ \\
\hline Metabolic syndrome (\%) & 54.5 & 75.3 & 69.2 & 84.2 & 0.010 \\
\hline Sodium $\left[\mathrm{mmol} / \mathrm{L}^{-1}\right]$ & $141 \pm 3$ & $143 \pm 2$ & $144 \pm 2$ & $143 \pm 2$ & $<0.001$ \\
\hline Potassium $\left[\mathrm{mmol} / \mathrm{L}^{-1}\right]$ & $4.3 \pm 0.4$ & $4.4 \pm 0.4$ & $3.7 \pm 0.5$ & $3.9 \pm 0.5^{3}$ & $<0.001$ \\
\hline Fasting glucose $\left[\mathrm{mmol} / \mathrm{L}^{-1}\right]$ & $5.6 \pm 0.6$ & $5.9 \pm 1.0$ & $5.7 \pm 0.5$ & $6.3 \pm 1.1$ & 0.007 \\
\hline Total cholesterol $\left[\mathrm{mmol} / \mathrm{L}^{-1}\right]$ & $5.2 \pm 1.1$ & $5.1 \pm 1.1$ & $4.9 \pm 0.9$ & $4.3 \pm 1.3$ & 0.012 \\
\hline LDL cholesterol $\left[\mathrm{mmol} / \mathrm{L}^{-1}\right]$ & $3.3 \pm 1.0$ & $3.3 \pm 1.0$ & $3.3 \pm 0.8$ & $2.6 \pm 1.0$ & 0.033 \\
\hline $\mathrm{HDL}$ cholesterol $\left[\mathrm{mmol} / \mathrm{L}^{-1}\right]$ & $1.4 \pm 0.4$ & $1.2 \pm 0.4$ & $1.4 \pm 0.4$ & $1.3 \pm 0.7$ & 0.047 \\
\hline Triglyceride $\left[\mathrm{mmol} / \mathrm{L}^{-1}\right]$ & $1.6 \pm 1.1$ & $1.8 \pm 0.9$ & $1.4 \pm 0.7$ & $1.3 \pm 0.7$ & 0.25 \\
\hline Creatinine level $\left[\mu \mathrm{mol} / \mathrm{L}^{-1}\right]$ & $76 \pm 18$ & $83 \pm 18$ & $82 \pm 23$ & $82 \pm 24$ & 0.14 \\
\hline eGFR $\left[\mathrm{mL} / \mathrm{min} / 1.73 \mathrm{~m}^{-2}\right]$ & $90.5 \pm 19.6$ & $90.3 \pm 20.2$ & $90.0 \pm 25.3$ & $93.6 \pm 26.0$ & 0.93 \\
\hline Microalbuminuria (\%) & 21.3 & 20.6 & 30.0 & $61.1^{2}$ & 0.003 \\
\hline Office SBP [mm Hg] & $159 \pm 23$ & $160 \pm 20$ & $156 \pm 13$ & $170 \pm 21$ & 0.23 \\
\hline Office DBP [mm Hg] & $95 \pm 15$ & $98 \pm 14$ & $92 \pm 12$ & $100 \pm 11$ & 0.33 \\
\hline Daytime SBP [mm Hg] & $144 \pm 20$ & $143 \pm 17$ & $154 \pm 17$ & $151 \pm 22$ & 0.13 \\
\hline Daytime DBP [mm Hg] & $89 \pm 13$ & $90 \pm 12$ & $92 \pm 10$ & $93 \pm 12$ & 0.53 \\
\hline Daytime heart rate (beats $/ \mathrm{min}^{-1}$ ) & $73 \pm 12$ & $72 \pm 10$ & $66 \pm 8$ & $67 \pm 10$ & 0.092 \\
\hline Night-time SBP [mm Hg] & $129 \pm 19$ & $130 \pm 15$ & $145 \pm 15$ & $144 \pm 23^{2}$ & 0.001 \\
\hline Night-time DBP [mm Hg] & $77 \pm 13$ & $79 \pm 11$ & $85 \pm 12$ & $84 \pm 11$ & 0.048 \\
\hline Night-time heart rate (beats $/ \mathrm{min}^{-1}$ ) & $66 \pm 11$ & $66 \pm 11$ & $63 \pm 9$ & $62 \pm 11$ & 0.51 \\
\hline
\end{tabular}

Data is presented as mean \pm SD or as median (interquartile range) unless otherwise stated; OSA — obstructive sleep apnoea; PA — primary aldosteronism; $2 \mathrm{hPG}-2 \mathrm{~h}$ post glucose loading; $\mathrm{BMI}$ - body mass index; eGFR — estimated glomerular filtration rate; ${ }^{*} \mathrm{p}<0.05 ; 0 \mathrm{BS}+\mathrm{PA}+v$. $0 \mathrm{BS}-\mathrm{PA}+;{ }^{1} \mathrm{p}<0.05 ;{ }^{2} \mathrm{p}<0.01$. ${ }^{3} \mathrm{p}<0.001 \mathrm{OBS}+\mathrm{PA}+v . \mathrm{OBS}+\mathrm{PA}-$

sults are presented as mean \pm one standard deviation or median and interquartile range. The values of variables between groups were compared - continuous and discrete variables: Mann-Whitney test or univariate ANOVA analysis with post-hoc t Dunnett test or T3 Dunnett test depending on Levene's test of homogeneity of variances; categorical variables: $\mathrm{chi}^{2}$ test or Fisher's exact test. $\mathrm{P}<0.05$ was considered statistically significant.

\section{Results}

Primary aldosteronism was diagnosed in $32(15.7 \%)$ out of 204 patients (123 M, 81 F, mean age 48.4, range
19-65 yrs) with true RHTN enrolled in the Resist-POL study. OSA occurred more frequently in patients with PA compared to patients without PA (59.4 v. 42.4\%, $p=0.058)$. AHI was higher in patients with PA compared to those without PA $(27.1 \pm 24.0$ v. $20.7 \pm 22.6$; $\mathrm{p}=0.024)$. Patients were divided into four groups based on the presence of PA and OSA: $\mathrm{PA}[+] \mathrm{OSA}[+], \mathrm{PA}[+]$ OSA[-], PA[-] OSA[+] and PA[-]OSA[-] (Table I).

Abdominal obesity, newly diagnosed diabetes, increased FPG and increased 2hPG concentrations were most frequent in the $\mathrm{PA}[+] \mathrm{OSA}[+]$ group compared to the other groups; no differences in the frequency of other MS components were observed (Table I). The fre- 
Table II. Echocardiographic parameters in relation to the presence of obstructive sleep apnoea (OSA) and primary aldosteronism (PA) Tabela II. Parametry echokardiograficzne w zależności od wspótistnienia obturacyjnego bezdechu sennego(OSA) i pierwotnego hiperaldosteronizmu (PA)

\begin{tabular}{|c|c|c|c|c|c|}
\hline & OSA- PA- & OSA+ PA- & OSA-PA+ & $\mathrm{OSA}+\mathrm{PA}+$ & p-value \\
\hline Subjects (n) & 99 & 73 & 13 & 19 & \\
\hline LVEDd [mm] & $51 \pm 5$ & $51 \pm 5$ & $55 \pm 4$ & $54 \pm 6$ & 0.018 \\
\hline LVESd [mm] & $31 \pm 4$ & $31 \pm 4$ & $34 \pm 5$ & $31 \pm 8$ & 0.23 \\
\hline IVSDd [mm] & $12 \pm 2$ & $13 \pm 2$ & $12 \pm 2$ & $14 \pm 2^{1, \#}$ & $<0.001$ \\
\hline PWDd [mm] & $12 \pm 2$ & $13 \pm 1$ & $12 \pm 2$ & $14 \pm 2^{1, \#}$ & $<0.001$ \\
\hline LA area $\left[\mathrm{cm}^{-2}\right]$ & $18.8 \pm 5.4$ & $19.7 \pm 5.2$ & $21.3 \pm 3.2$ & $22.2 \pm 4.6$ & 0.073 \\
\hline $\mathrm{EF}(\%)$ & $70 \pm 5$ & $70 \pm 5$ & $67 \pm 7$ & $67 \pm 10$ & 0.095 \\
\hline GLS (\%) & $-15.1 \pm 3.8$ & $-13.2 \pm 3.5$ & $-15.8 \pm 2.4$ & $-13.2 \pm 3.6$ & 0.006 \\
\hline E/A (ratio) & $1.2 \pm 0.4$ & $1.0 \pm 0.4$ & $1.2 \pm 0.4$ & $1.0 \pm 0.4$ & 0.010 \\
\hline $\mathrm{E}^{\prime}$ (wave $\mathrm{cm} / \mathrm{s}^{-1}$ ) & $11.1 \pm 3.4$ & $9.3 \pm 2.7$ & $10.4 \pm 3.6$ & $7.0 \pm 2.8^{1, *}$ & $<0.001$ \\
\hline E/E' (ratio) & $7.7 \pm 2.5$ & $8.9 \pm 2.9$ & $8.1 \pm 2.5$ & $11.7 \pm 4.0^{2, \#}$ & $<0.001$ \\
\hline RWT (ratio) & $0.46 \pm 0.07$ & $0.50 \pm 0.07$ & $0.44 \pm 0.06$ & $0.54 \pm 0.11^{\#}$ & $<0.001$ \\
\hline RWT $\geq 0.45(\%)$ & 49.5 & 75.0 & 27.3 & $84.2^{\#}$ & $<0.001$ \\
\hline LVM [g] & $234 \pm 61$ & $267 \pm 62$ & $273 \pm 85$ & $328 \pm 88^{2}$ & $<0.001$ \\
\hline LVMI $\left[\mathrm{m} / \mathrm{g}^{-2}\right]$ & $121 \pm 28$ & $128 \pm 28$ & $138 \pm 35$ & $159 \pm 39^{3}$ & $<0.001$ \\
\hline LVH (\%) & 43.9 & 56.9 & 72.7 & $84.2^{1}$ & 0.005 \\
\hline
\end{tabular}

Data is presented as mean \pm SD unless otherwise stated; OSA — obstructive sleep apnoea; PA — primary aldosteronism; LVEDd — end-diastolic left ventricular diameter; LVEDs — end-systolic left ventricular diameter; IVSDd — interventricular septum thickness; PWDd — posterior wall thickness; LA — left atrium; EF — ejection fraction; GLS — global longitudinal strain; E/A — ratio of the early to late diastolic peak transmitral flow velocity; $E^{\prime}$ — tissue Doppler of early-diastolic ventricular filling velocity; E/E' — ratio: ratio of early diastolic pulsed wave Doppler to early diastolic tissue Doppler; RWT — relative wall thickness; LVM — left ventricular mass; LVMI - left ventricular mass index, ${ }^{*} \mathrm{p}<0.05 ;{ }^{*} \mathrm{p}<0.01 ; 0 \mathrm{BS}+\mathrm{PA}+v$. OBS- PA+; ${ }^{1} \mathrm{p}<0.05 ;{ }^{2} \mathrm{p}<0.01 ;{ }^{3} \mathrm{p}<0.0010 \mathrm{BS}+\mathrm{PA}+v$. $0 \mathrm{BS}+\mathrm{PA}-$

quency of microalbuminuria was highest in the PA[+] OSA $[+]$ group compared to the other groups (Table I).

The frequency of LVH was higher in the PA $[+] \mathrm{OSA}[+]$ group compared to the $\mathrm{PA}[-] \mathrm{OSA}[+]$ group, and concentric remodelling was more frequent in the $\mathrm{PA}[+] \mathrm{OSA}[+]$ group compared to the $\mathrm{PA}[+] \mathrm{OSA}[-]$ group (Table II). In the PA $[+] \mathrm{OSA}[+]$ and $\mathrm{PA}[-] \mathrm{OSA}[+]$ groups, the most frequent LV geometry pattern was concentric hypertrophy and in the PA $[+] \mathrm{OSA}[-]$ groups the most frequent was eccentric hypertrophy (Fig. 1). E' velocity was lower and $\mathrm{E} / \mathrm{E}^{\prime}$ was hFigher in the $\mathrm{PA}[+] \mathrm{OSA}[+]$ group compared to all other groups. GLS was higher in patients with OSA compared to those without OSA (Table I).

\section{Discussion}

An interesting finding of our study is a high coexistence of clinically significant moderate-severe OSA in patients with PA. In patients with PA, the severity of OSA was more pronounced compared to those without PA. Also in patients with PA and OSA, glucose metabolism alterations were most pronounced.

In one study of 109 patients with resistant hypertension, OSA was found in $84 \%$ of patients with PA, supporting the concept that in subjects with resistant

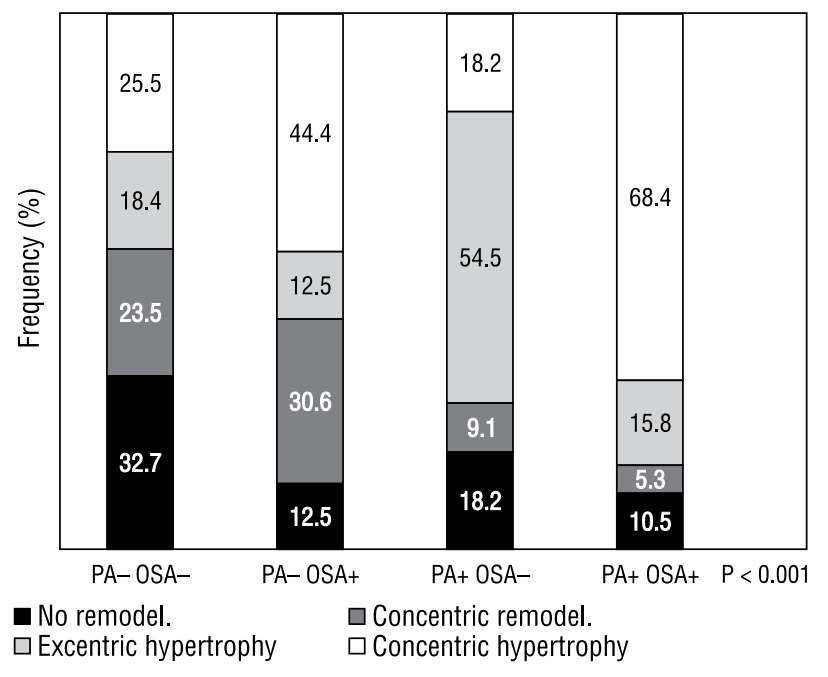

Figure 1. Frequency of left ventricular geometry patterns in relation to the presence of obstructive sleep apnea (OSA) and primary aldosteronism (PA)

Rycina 1. Częstość występowania typów geometrii lewej komory w zależności od wspótistnienia obturacyjnego bezdechu sennego (OBS) i pierwotnego hiperaldosteronizmu (PA)

hypertension, the severity of OSA is greater in those patients with hyperaldosteronism and correlates with the degree of aldosterone access [12]. In another study 
in 325 newly diagnosed hypertensive patients who were screened for the presence of OSA, 53 patients were confirmed to have OSA; out of these patients, $34 \%$ had PA. This supports a high prevalence of PA in patients with OSA [11].

The pathophysiologic mechanism underlying the co-occurrence of these conditions is at present unknown and needs further elucidation. Inappropriate sodium and fluid retention characterise hyperaldosteronism, including patients with RHTN. Displacing fluid from the lower extremities to the neck results in upper airway narrowing, suggesting that upper airway oedema may contribute importantly to the pathogenesis of OSA in patients with PA and RHTN [1].

Previous studies showed that OSA or PA are associated with high prevalence of $\operatorname{LVH}[2,5,10,20]$. Our study showed that $\mathrm{LVH}$ and changes in diastolic function were more pronounced in patients with PA coexisting with OSA compared to patients with only one of these comorbidities. It is of interest that PA and OSA influence differently left ventricular geometry. The presence of OSA was associated with concentric remodelling, and the presence of PA was associated with higher left ventricular mass and higher frequency of left ventricular hypertrophy. Therefore patients with PA and OSA were characterised by frequent concentric hypertrophy, but patients with PA without OSA were characterised by frequent eccentric hypertrophy. Also Savard et al. compared patients with PA and essential hypertension and found greater LVMI and a higher prevalence of $\mathrm{LVH}$ in patients with PA [20]. Although it might be postulated that the inappropriate sodium and fluid retention characterising hyperaldosteronism might contribute to the development of LVH [21], other factors such as the co-existence of OSA may determine the LV geometry.

There were no differences between the analysed groups in terms of systolic function assessed by the ejection fraction. However, using a new method known as speckle tracking echocardiography we found subclinical systolic dysfunction in patients with OSA with or without PA. This finding confirms the significant impact of OSA on systolic function. It was supported by the results of Usui et al. that patients with OSA have worsened systolic function as assessed by the STE method [22].

It is also of interest that in our study we found that diastolic parameters were the most severely impaired in a group with coexisting OSA and PA. It may be secondary to $\mathrm{LVH}$, cyclic ischaemia that is present in OSA, as well as to influence of aldosterone on increased myocardial fibrosis.

In summary, the results indicate a high prevalence of OSA in patients with RHTN and PA. This may suggest that in patients with RHTN, PA may contribute to the increased severity of OSA, but it does not exclude the reverse, i.e. that OSA stimulates aldosterone release in these patients. This may also explain why patients with PA coexisting with OSA were characterised by more pronounced metabolic abnormalities and changes in cardiac structure than those without PA. It is also of interest that PA and OSA influenced differently LV geometry - PA was associated with more pronounced LVH, whereas OSA was associated with more pronounced concentric remodelling.

\section{References}

1. Dudenbostel T, Calhoun DA. Resistant hypertension, obstructive sleep apnoea and aldosterone. J Hum Hypertens. 2012; 26: 281-287.

2. Maria Czarina Acelajado and David A. Calhoun, "Aldosteronism and Resistant Hypertension," International Journal of Hypertension, vol. 2011, Article ID 837817, 7 pages, 2011. doi:10.4061/2011/837817

3. Mysliwiec J, Gorska M. Primary aldosteronism: a common and important problem. A practical guide to the diagnosis and treatment. Endokrynol Pol 2012; 63: 324-336.

4. Lubikowski J, Kiedrowicz B, Szajko M et al. Laparoscopic adrenalectomy for functioning and non-functioning adrenal tumours. Endokrynol Pol 2011; 62: 512-516.

5. Born-Frontsberg E, Reincke M, Rump LC et al. Cardiovascular and cerebrovascular comorbidities of hypokalemic and normokalemic primary aldosteronism: results of the German Conn's Registry. J Clin Endocrinol Metab 2009; 94: 1125-1130.

6. Florczak E, Prejbisz A, Szwench-Pietrasz E et al. Clinical characteristics of patients with resistant hypertension: the RESIST-POL study. J Hum Hypertens 2013.

7. Pedrosa RP, Drager LF, Gonzaga CC et al. Obstructive sleep apnea: the most common secondary cause of hypertension associated with resistant hypertension. Hypertension 2011; 58: 811-817.

8. Inal S, Karakoc MA, Kan E et al. The effect of overt and subclinical hypothyroidism on the development of non-dipper blood pressure. Endokrynol Pol 2012; 63: 97-103.

9. Gami AS, Somers VK. Obstructive sleep apnoea, metabolic syndrome, and cardiovascular outcomes. Eur Heart J 2004; 25: 709-711.

10. Jozwik-Plebanek K, Prejbisz A, Janaszek-Sitkowska H et al. Obstructive sleep apnea and cardio-vascular damage. Kardiol Pol 2012; 70: 735-740.

11. Di Murro A, Petramala L, Cotesta D et al. Renin-angiotensin-aldosterone system in patients with sleep apnoea: prevalence of primary aldosteronism. J Renin Angiotensin Aldosterone Syst 2010; 11: 165-172.

12. Gonzaga CC, Gaddam KK, Ahmed MI et al. Severity of obstructive sleep apnea is related to aldosterone status in subjects with resistant hypertension. J Clin Sleep Med 2010; 6: 363-368.

13. Mancia G, De Backer G, Dominiczak A et al. 2007 Guidelines for the Management of Arterial Hypertension: The Task Force for the Management of Arterial Hypertension of the European Society of Hypertension (ESH) and of the European Society of Cardiology (ESC). J Hypertens 2007; 25: 1105-1187.

14. Funder JW, Carey RM, Fardella $\mathrm{C}$ et al. Case detection, diagnosis, and treatment of patients with primary aldosteronism: an endocrine society clinical practice guideline. J Clin Endocrinol Metab 2008; 93: 3266-3281.

15. Mysliwiec J, Zukowski L, Grodzka A et al. Diagnostics of primary aldosteronism: is obligatory use of confirmatory tests justified? J Renin Angiotensin Aldosterone Syst 2012; 13: 367-371.

16. Mysliwiec J, Zukowski L, Grodzka A et al. Problems in diagnostics of primary aldosteronism - analysis of the own data. Endokrynol Pol 2010; 61: 2-5.

17. Podgorska J, Cieszanowski A, Bednarczuk T. Adrenal imaging. Endokrynol Pol 2012; 63: 71-81.

18. Devereux RB, Reichek N. Echocardiographic determination of left ventricular mass in man. Anatomic validation of the method. Circulation 1977; 55: 613-618.

19. Krumholz HM, Larson M, Levy D. Prognosis of left ventricular geometric patterns in the Framingham Heart Study. J Am Coll Cardiol 1995; 25: 879-884.

20. Savard S, Amar L, Plouin PF, Steichen O. Cardiovascular Complications Associated With Primary Aldosteronism: A Controlled Cross-Sectional Study. Hypertension 2013.

21. Prejbisz A, Klisiewicz A, Januszewicz A et al. 22-Year-old patient with malignant hypertension associated with primary aldosteronism. J Hum Hypertens 2013; 27: 138-140.

22. Usui $Y$, Takata Y, Inoue $Y$ et al. Coexistence of obstructive sleep apnoea and metabolic syndrome is independently associated with left ventricular hypertrophy and diastolic dysfunction. Sleep Breath 2012; 16: 677-684. 